\title{
Effects of phytoestrogen on sexual development
}

Shin Hye Kim, MD, Mi Jung Park, MD, PhD

Department of Pediatrics, Sanggye Paik Hospital, Inje

University College of Medicine, Seoul, Korea
Phytoestrogen is an estrogenic compound that occurs naturally in plants. The most common sources of phytoestrogen are soybean products, which contain high levels of isoflavones. This compound, which has structural similarity with estrogen, can act as an estrogen receptor agonist or antagonist. Animal studies provide evidence of the significant effects of phytoestrogen on sexual development, including altered pubertal timing, impaired estrous cycling and ovarian function, and altered hypothalamus and pituitary functions. Although human studies examining the effects of phytoestrogen on sexual development are extremely limited, the results of some studies agree with those of the animal studies. In this paper, we review the possible mechanism of phytoestrogen action and the evidence showing the effects of phytoestrogen on sexual development in animal and human studies.

Key words: Phytoestrogens, Puberty, Sexual development
Received: 3 May 2012, Accepted: 27 June 2012

Corresponding author: Mi Jung Park, MD, PhD

Department of Pediatrics, Sanggye Paik Hospital, Inje University College of Medicine, 1342 Dongil-ro, Nowon-gu, Seoul 139-707, Korea

Tel: +82-2-950-1130, Fax: +82-2-951-1246

E-mail: PMJ@paik.ac.kr

\section{Introduction}

Phytoestrogen is a plant-derived compound that mimics estrogen ${ }^{1)}$. Phytoestrogens can be classified as isoflavones, coumestans, and lignans (Fig. 1). Isoflavones, which are the most extensively studied phytoestrogens, are found predominately in soybeans and soy product-containing foods ${ }^{2}$. The major isoflavones are genistein and daidzein, and their conjugates account for greater than $65 \%$ of the total isoflavones".

Phytoestrogen has significant binding affinity to estrogen receptor (ER), although much weaker than that of estradiol. Experimental animal studies have demonstrated several adverse effect of isoflavones on the reproductive system, such as premature pubertal onset ${ }^{4,5)}$, reduced fertility ${ }^{6,7)}$, altered estrous cyclicity ${ }^{5,8)}$, and disrupted pituitary responsiveness to gonadotropin releasing hormone $(\mathrm{GnRH})^{9)}$. Therefore, concerns over the possible adverse effects of phytoestrogens on reproductive health have been raised in humans as well.

Studies on the hormonal effects of isoflavones are especially impor- tant in Koreans because soy products are a major component of the Korean diet; in fact, the consumption of an isoflavone-containing diet such as soy-based infant formula and soy-fortified foods and beverages has recently increased. In this paper, we review the possible mode of actions of phytoestrogen and summarize the results of animal and human studies showing the effects of phytoestrogens on sexual development, especially in childhood.

\section{Mode of phytoestrogen action and target tissues}

Estrogens act through 2 subtypes of their receptors found in target tissues: ER $\alpha$ and ER $\beta$. Both ERs are widely expressed in various mammalian tissues; however, there are some differences in their distribution. ER $\alpha$ is most abundant in the uterus, and smaller quantities are detected in the ovaries, Leydig cells of the testes, female mammary glands, bones, and hypothalamus ${ }^{10,11}$. ER $\beta$ expression is highest in ovarian granulose cells and the gastrointestinal tract, whereas it is moderate to low in spermatids, the prostate, epididymis, 


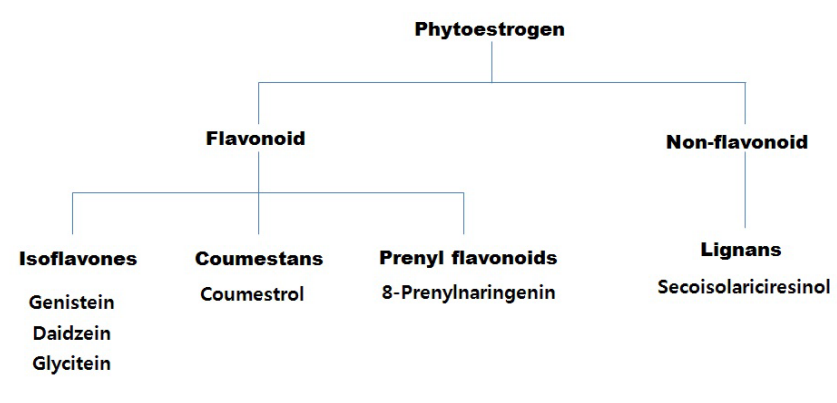

Fig. 1. Classification of phytoestrogens.<smiles>O=c1c(-c2ccc(O)cc2)coc2cc(O)cc(O)c12</smiles><smiles>O=c1c(-c2ccc(O)cc2)coc2cc(O)ccc12</smiles>

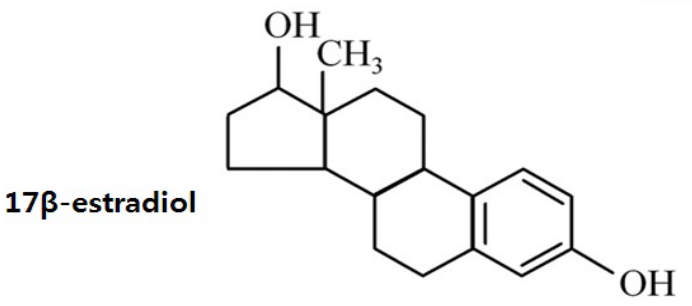

Fig. 2. Molecular structure of isoflavones.

female mammary glands, hypothalamus, and pituitary gland ${ }^{11,12)}$.

The structure of isoflavones is closely similar to that of estrogens ${ }^{13)}$. The presence of the 2 phenolic rings in isoflavones enables these compounds to bind to ERs (Fig. 2). Isoflavones exert estrogenic effects on a number of target organs that possess ER $\alpha$ and/or ER $\beta$. Although the binding affinities to ER $\alpha$ and $E R \beta$ of isoflavones is much lower than those of $17 \beta$-estradiol, they can compete with $17 \beta$-estradiol for binding to the $E R \alpha$ and $E R \beta^{1)}$. The binding affinity of genistein for $E R \beta$ is $87 \%$, while that for ER $\alpha$ is $4 \%$, while that of daidzein for $E R \beta$ and ER $\alpha$ is $0.5 \%$ and $0.1 \%$, respectively ${ }^{14}$. The effect of phytoestrogen has been demonstrated to be either agonistic or antagonistic depending on its own concentrations ${ }^{15)}$ or the estrogen concentrations of the environment ${ }^{16)}$. At low concentrations, genistein appears to act as an agonist, stimulating the proliferation of estrogen-dependent breast cancer cells, whereas high concentrations inhibit estradiolstimulated cell growth ${ }^{17)}$. Hwang et al. ${ }^{16)}$ showed that isoflavone metabolites act as ER agonists in a low-estrogen environment (postmenopausal level of estradiol) but act as ER antagonists in a high-estrogen environment (premenopausal level of estradiol).

\section{Phytoestrogen exposure and sexual development in animals}

A number of animal studies have shown the adverse effects of phytoestrogens on reproductive organs (Table 1). Exposure to genistein affects mammary gland development and differentiation in rodents. Chronic genistein exposure from gestation day (GD) 7 to postnatal day (PND) 50 has been shown to result in ductal/alveolar hyperplasia of the mammary gland in pups ${ }^{18)}$. Neonatal female mice treated with genistein showed a differential effect on mammary gland growth according to genistein dosage: low dose-treated mice exhibited advanced maturation with increased ductal elongation, whereas high dose-treated mice showed reduced lobular alveolar development ${ }^{19)}$.

In the aspect of pubertal onset, the effects of phytoestrogens are quite different according to exposure time, dosage, and route. Signs of pubertal onset in rats/mice are vaginal opening in females and preputial separation in males. One study demonstrated that perinatal exposure to genistein did not affect the age of pubertal onset in male and female rats ${ }^{20}$. However, other studies found that dietary exposure to high doses of isoflavone from GD 1 to PND 21 induced the acceleration of vaginal opening in female offspring but did not affect preputial separation in male offspring ${ }^{21,22)}$. Short-term exposure to high doses of isoflavone in the neonatal period has also been shown to expedite vaginal opening in female rats ${ }^{5,8,23}$. In fact, we recently found that exposure to high doses of genistein in the prepubertal period (from PND 21 until puberty) induces early vaginal opening in female rats ${ }^{4}$.

The adverse effects of genistein exposure on the developing ovaries have been shown in rodent studies. At birth, mice have large oocyte nests, and during the first week of life, these oocyte nests dissociate into individual oocytes surrounded by granulose cells ${ }^{24)}$. This ovarian differentiation process requires a postpartum decrease in estrogen and progesterone ${ }^{24)}$. Neonatal treatment with estrogen compounds such as $17 \beta$-estradiol and genistein disrupts this process, leaving the oocytes together in nests and leading to multi-oocyte follicles $(\mathrm{MOF} s)^{7,25,26)}$. Since MOF-derived oocytes have been observed to have reduced fertility rates during in vitro fertilization ${ }^{27)}$, an increased number of MOFs is one possible explanation for infertility in genistein-treated rodents ${ }^{28)}$.

Numerous studies have shown that exposure of rodents to genistein in the neonatal period caused abnormal estrous cyclicity ${ }^{5,78}$ and altered ovulation $^{6,25}$. These phenomena are mainly explained by the effect of genistein on the hypothalamic-pituitary-gonadal (HPG) axis, 
Table 1. Animal Studies Investigating the Effects of Phytoestrogens on Sexual Development

\begin{tabular}{|c|c|c|c|c|c|}
\hline Phytoestrogen & $\begin{array}{l}\text { Species } \\
\text { (gender) }\end{array}$ & Age at treatment & Dose, route & Effects & Reference \\
\hline Geistein & Rat (F) & GD 7-PND 50 & 1,250 ppm, PO & Ductal/alveolar hyperplasia of MG & Delclos et al. ${ }^{18)}$ \\
\hline Genistein & Mice (F) & PND 1-5 & $\begin{array}{l}0.5 \mathrm{mg} / \mathrm{kg} / \text { day, } \mathrm{SQ} \\
50 \mathrm{mg} / \mathrm{kg} / \mathrm{day}\end{array}$ & $\begin{array}{l}\text { Advanced alveolar maturation of MG at } 5 \text { wk } \\
\text { Reduced alveolar maturation of MG at } 5 \text { wk }\end{array}$ & Padilla-Banks et al. ${ }^{19)}$ \\
\hline Genistein & Rat $(F)$ & GD 15-PND 11 & 1,250 ppm, PO & $\begin{array}{l}\text { No effect on VO } \\
\text { Irregular estrous cyclicity (extended diestrus) }\end{array}$ & Takagi et al. ${ }^{20)}$ \\
\hline Isoflavones & Mice (F) & GD 1-PND 21 & $0.05 \%$ isoflavone-diet & Early VO Increased incidence of MOFs & Takashima-Sasaki et al. ${ }^{21)}$ \\
\hline Genistein & $\operatorname{Rat}(F)$ & GD 1-PND 21 & $0.02 \%, 0.1 \%$ genistein-diet & Early VO & Casanova et al. ${ }^{22)}$ \\
\hline Genistein & Rat (F) & PND 1-5 & $1 \mathrm{mg} /$ day, $\mathrm{SQ}$ & $\begin{array}{l}\text { Early VO } \\
\text { Irregular estrous cyclicity (extended estrus) }\end{array}$ & Kouki et al. ${ }^{8)}$ \\
\hline Genistein & Rat $(F)$ & PND 1-21 & $\begin{array}{l}40 \mathrm{mg} / \mathrm{kg} / \mathrm{day} \\
\text { PND 1-7, SQ } \\
\text { PND 8-21, PO }\end{array}$ & $\begin{array}{l}\text { Early VO } \\
\text { Irregular estrous cyclicity (extended estrus) }\end{array}$ & Lewis et al. ${ }^{23)}$ \\
\hline Genistein & $\operatorname{Rat}(F)$ & PND 1-4 & 10 mg/kg/day, SQ & $\begin{array}{l}\text { Early VO; Irregular estrous cyclicity; decreased } \\
\text { GnRH activation }\end{array}$ & Bateman and Patisaul ${ }^{5)}$ \\
\hline Genistein & $\operatorname{Rat}(F)$ & $\begin{array}{l}\text { PND } 21 \\
\text {-Puberal onset }\end{array}$ & 10,100 mg/kg/day, PO & Early VO & Lee et al. ${ }^{4)}$ \\
\hline Genistein & Mice (F) & PND 1-5 & $\begin{array}{l}1,10,100 \text { micg, } P O \\
1 \text { micg } \\
10,100 \text { micg }\end{array}$ & $\begin{array}{l}\text { Increased MOFs at PND } 19 \\
\text { Increased number of ovulated oocytes } \\
\text { Decreased number of ovulated oocytes }\end{array}$ & Jefferson et al. ${ }^{25)}$ \\
\hline Genistein & Mice (F) & PND 1-5 & $5,20,50,100 \mathrm{mg} / \mathrm{kg} / \mathrm{day}, \mathrm{PO}$ & $\begin{array}{l}\text { Increased incidence of MOFs in the neonate } \\
\text { persisted into adulthood ( } 4 \text { mo old) }\end{array}$ & Cimafranca et al. ${ }^{26)}$ \\
\hline Genistein & $\operatorname{Rat}(F)$ & PND 1-5 & $12.5,25,50,100 \mathrm{mg} / \mathrm{kg} /$ day, $\mathrm{PO}$ & $\begin{array}{l}\text { Increased incidence of MOFs; decreased fertility } \\
\text { rate; no effect on VO }\end{array}$ & Nagao et al. ${ }^{7)}$ \\
\hline Genistein & Mice (F) & PND 1-5 & $\begin{array}{l}5,50 \mathrm{mg} / \mathrm{kg} / \text { day, } \mathrm{PO} \\
5 \mathrm{mg} / \mathrm{kg} / \text { day } \\
50 \mathrm{mg} / \mathrm{kg} / \text { day }\end{array}$ & $\begin{array}{l}\text { Irregular estrous cyclicity (extended estrus) } \\
\text { Increased ovulation } \\
\text { Decreased ovulation }\end{array}$ & Jefferson et al..$^{6)}$ \\
\hline Genistein & $\operatorname{Rat}(\mathrm{F})$ & PND 0-3 & 10 mg/kg/day, SQ & $\begin{array}{l}\text { Decreased kisspeptin fiber density in AVPV } \\
\text { early VO; increased MOFs at PND } 24\end{array}$ & Losa et al. ${ }^{30)}$ \\
\hline Genistein & $\operatorname{Rat}(\mathrm{F})$ & PND 1-10 & $1-1,000$ micg/day, $S Q$ & $\begin{array}{l}10 \text { micg increased LH release to } \mathrm{GnRH} \\
100-500 \text { micg decreased LH release to } \mathrm{GnRH}\end{array}$ & Faber and Hughes' ${ }^{9)}$ \\
\hline Genistein & Rat (M) & GD 7-PND 50 & $\begin{array}{l}1,250 \mathrm{ppm} \\
625-1,250 \mathrm{ppm} \\
250-1,250 \mathrm{ppm}\end{array}$ & $\begin{array}{l}\text { Decreased ventral prostate weight } \\
\text { Delayed spermatogenesis } \\
\text { Decreased sperm counts in the epididymis } \\
\text { Ductal/alveolar hyperplasia }\end{array}$ & Delclos et al. ${ }^{18)}$ \\
\hline Genistein & Rat (M) & GD 15-PND 11 & 1,250 ppm, PO & $\begin{array}{l}\text { No effect on PPS } \\
\text { No effect on weights of pituitary, adrenal, } \\
\text { and ventral prostate }\end{array}$ & Takagi et al. ${ }^{20)}$ \\
\hline Isoflavones & $\operatorname{Mice}(\mathrm{M})$ & GD 1-PND 21 & $0.05 \%$ isoflavone-diet & No effect on PPS and weight of testes & Takashima-Sasaki et al. ${ }^{21)}$ \\
\hline Genistein & Rat (M) & GD 1-PND 21 & $0.02 \%, 0.1 \%$ genistein-diet & $\begin{array}{l}\text { No effect on PPS and weights of testes } \\
\text { and ventral prostate }\end{array}$ & Casanova et al. ${ }^{22)}$ \\
\hline Genistein & Rat (M) & PND 1-5 & $\begin{array}{l}12.5,25,50,100 \\
\mathrm{mg} / \mathrm{kg} / \mathrm{day}, \mathrm{PO}\end{array}$ & $\begin{array}{l}\text { No effect on PPS and fertility rate } \\
\text { No histological change in the gonads }\end{array}$ & Nagao et al." \\
\hline
\end{tabular}

GD, gestational day; PND, postnatal day; PO, per oral; MG, mammary gland; SQ, subcutaneous injection; VO, vaginal opening; MOFs, multi-oocyte follicles; $\mathrm{GnRH}$, gonadotropin releasing hormone; AVPV, anteroventral periventricular nucleus; PPS, preputial separation.

upon which normal estrous cyclicity is dependent ${ }^{6}$ and from which a mid-cycle surge of luteinizing hormone (LH) for ovulation is derived $^{29)}$. The response of the HPG axis in the neonatal period to genistein exposure seems to be dose-dependent. One study demonstrated that exposure to low doses of genistein in the neonatal period increased GnRH-induced LH release, whereas a high dose of genistein decreased GnRH-induced LH release ${ }^{9)}$. Similarly, mice treated neonatally with low doses of genistein showed increased LH production and enhanced ovulation ${ }^{6,25)}$, whereas rats exposed to high doses of genistein in the neonatal period demonstrated decreased $\mathrm{GnRH}$ activation and kisspeptin fiber density in the hypothalamus ${ }^{5,30)}$. These data suggest that exposure to genistein in 
the neonatal period disrupts HPG function in a dose-dependent manner.

Relatively few studies have demonstrated the effects of phytoestrogen on male sexual development in rodents. Delclos et al. ${ }^{18)}$ showed decreased ventral prostate weight and delayed spermatogenesis in male rats after genistein exposure from conception to puberty. However, exposure for short duration (GD 1 to the prepubertal period) did not affect pubertal timing, gonadal weight/ histology, or fertility rate in male rodents ${ }^{720-22)}$.

\section{Phytoestrogen exposure and sexual development in children}

Human phytoestrogen exposure is highly dependent on the con- sumption of soy-based foods. The traditional Asian diet includes greater amounts of soy products such as tofu, soy sauce, and tempeh than the typical Western diet; therefore, the Asian population has higher concentrations of isoflavone in the urine and plasma than the Western population ${ }^{31-33)}$. Because phytoestrogens cross the placenta, fetuses are exposed to them through maternal dietary consumption ${ }^{34)}$. After birth, infants are exposed to phytoestrogens though breastfeeding; however, the most extensive exposure to phytoestrogens occurs via soy-based formula feeding ${ }^{35}$.

A few studies have investigated the relationship between phytoestrogen exposure and sexual development in children, and an association was mainly reported in girls (Table 2). Neonatal consumption of soy-based formula was independently associated with premature thelarche in Puerto Rican girls ${ }^{36}$. Zung et al. ${ }^{37)}$ also reported that

Table 2. Human Studies Investigating the Effects of Phytoestrogens on Sexual Development

\begin{tabular}{|c|c|c|c|}
\hline Study population (sample size) & Method & Findings & Reference \\
\hline $\begin{array}{l}\text { Puerto Rican, girls aged } 6 \text { mo-8 yr } \\
\text { (130 PT cases, } 130 \text { controls) }\end{array}$ & $\begin{array}{l}\text { Cross-sectional study } \\
\text { Assessment of breast bud }\end{array}$ & $\begin{array}{l}\text { Positive association between PT and } \\
\text { consumption of soy-based formula }\end{array}$ & Freni-Titulaer et al. $^{36)}$ \\
\hline $\begin{array}{l}\text { Israel, female infants (total } 694 \text {, soy formula } \\
\text { feeding 92) }\end{array}$ & $\begin{array}{l}\text { Cross-sectional study } \\
\text { Assessment of breast bud }\end{array}$ & $\begin{array}{l}\text { Positive association between PT and } \\
\text { consumption of soy-based formula }\end{array}$ & Zung et al. ${ }^{37)}$ \\
\hline US, infants (35 girls) & $\begin{array}{l}\text { Follow-up study } \\
\text { Assessment of breast bud, } \\
\text { vaginal wall cells }\end{array}$ & $\begin{array}{l}\text { Girls fed soy-formula showed } \\
\text { re-estrogenization at } 6 \text { months } \\
\text { in vaginal wall cell maturation index }\end{array}$ & Bernbaum et al. ${ }^{38)}$ \\
\hline $\begin{array}{l}\text { US, females aged } 20-34 \text { yr (128 fed soy, } 268 \\
\text { fed cow milk formula in infancy) }\end{array}$ & $\begin{array}{l}\text { Retrospective cohort study } \\
\text { Assessed pubertal timing by } \\
\text { telephone interview }\end{array}$ & $\begin{array}{l}\text { No difference in pubertal timing } \\
\text { between groups }\end{array}$ & Strom et al. ${ }^{39)}$ \\
\hline US, New York girls aged 9 yr (192) & $\begin{array}{l}\text { Cross-sectional study } \\
\text { Assessment of Tanner stages }\end{array}$ & $\begin{array}{l}\text { A negative trend for urine daidzein and } \\
\text { genistein levels with breast development }\end{array}$ & Wolff et al. ${ }^{40)}$ \\
\hline German, girls (119) & $\begin{array}{l}\text { Cohort study } \\
\text { Assessment of dietary intake, } \\
\text { breast development }\end{array}$ & $\begin{array}{l}\text { A negative trend for dietary isoflavones } \\
\text { with breast development in girls } \\
\text { No association for urinary isoflavone } \\
\text { levels with pubertal markers }\end{array}$ & Cheng et al. ${ }^{41)}$ \\
\hline UK, girls $(2,920)$ & $\begin{array}{l}\text { Prospective study } \\
\text { Assessed age at menarche } \\
\text { by annual questionnaire }\end{array}$ & $\begin{array}{l}\text { Girls fed soy-formula in early infancy } \\
\text { have an increased risk of menarche }\end{array}$ & Adgent et al. ${ }^{42)}$ \\
\hline Korea, girls (108 CPP cases, 91 controls) & $\begin{array}{l}\text { Case-control study } \\
\text { Assessed Tanner stage, bone age, } \\
\text { GnRH stimulation test }\end{array}$ & $\begin{array}{l}\text { A positive association between CPP } \\
\text { risk and high serum isoflavone level }\end{array}$ & Kim et al. ${ }^{43)}$ \\
\hline US, infants (37 boys) & $\begin{array}{l}\text { Follow-up study } \\
\text { Assessment scrotal anatomy or } \\
\text { testicular volume }\end{array}$ & No difference in genital development & Bernbaum et al. ${ }^{38)}$ \\
\hline $\begin{array}{l}\text { US, males aged 20-34 yr ( } 120 \text { fed soy, } \\
295 \text { fed cow millk formula in infancy) }\end{array}$ & $\begin{array}{l}\text { Retrospective cohort study } \\
\text { Assessed pubertal timing by } \\
\text { telephone interview }\end{array}$ & $\begin{array}{l}\text { No difference in pubertal timing between } \\
\text { groups }\end{array}$ & Strom et al..$^{39)}$ \\
\hline German, boys (108) & $\begin{array}{l}\text { Cohort study } \\
\text { Assessment of dietary intake, } \\
\text { gonadal development }\end{array}$ & $\begin{array}{l}\text { No association with gonadal development } \\
\text { in boys } \\
\text { No association for urinary isoflavone } \\
\text { levels with pubertal markers }\end{array}$ & Cheng et al. ${ }^{41)}$ \\
\hline $\begin{array}{l}\text { UK, boys (total 7,928, } 51 \text { hypospadias } \\
\text { cases) }\end{array}$ & $\begin{array}{l}\text { Prospective study; Assessed life } \\
\text { style and dietary practices by } \\
\text { questionnaire during pregnancy }\end{array}$ & $\begin{array}{l}\text { Increased risk of giving birth to a boy } \\
\text { with hypospadias in vegetarian } \\
\text { mothers compared with omnivors }\end{array}$ & North and Golding ${ }^{45)}$ \\
\hline
\end{tabular}

PT, premature thelarche; US, United States; UK, United Kingdom; CPP, central precocious puberty. 
premature thelarche was more prevalent among soy formula-fed infants. In addition, the estrogenic activity of soy-based formula in infants involves vaginal cell maturation ${ }^{38)}$. Vaginal wall cells show maximal maturation index at birth due to maternal estrogen and then rapidly lose the estrogen effect by the age of 1 month. This low maturation index is maintained in breast milk- or cow-based formula-fed infants; in contrast, the vaginal maturation index rises again in infants fed soybased formula by the age of 6 months, indicating the estrogen activity of soy-based formula.

There are conflicting results in regard with pubertal timing. A telephone survey of young adults who had been fed soy formula during the infancy reported no significant changes in pubertal maturation $^{39)}$. Two studies reported that phytoestrogen exposure was associated with delayed puberty in girls. A cross-sectional study of 192 healthy 9-year-old girls found that delayed breast development was observed in girls with high concentrations of urinary daidzein and genistein $^{40)}$. A prospective cohort study reported that high isoflavone intake was associated with delayed breast development in German girls $^{41)}$. On the other hand, recent studies support that phytoestrogen exposure may induce earlier pubertal maturation. A prospective longitudinal study that enrolled pregnant women in the United Kingdom reported that early soy-fed infants had earlier menarche compared with girls fed breast milk or other types of formula ${ }^{42)}$. We recently demonstrated that high serum isoflavone levels are associated with central precocious puberty in Korean girls ${ }^{43)}$.

These conflicting results reflect the complex influence of phytoestrogens on the HPG axis. The effects of isoflavones on puberty seems be dependent on several factors, such as the amount of isoflavones consumed, timing of isoflavone exposure, and endogenous estrogen status of individuals. As discussed earlier, genistein exposure alters GnRH activation and pituitary responsiveness; specifically, a low dose of genistein increased GnRH-induced LH release, whereas a high dose of genistein decreased GnRH-induced LH release ${ }^{9)}$. In the peripubertal period when endogenous estradiol levels are low, phytoestrogen exposure could induce increased sensitivity of the pituitary gland to $\mathrm{GnRH}$ challenge ${ }^{9}$, whereas exposure after pubertal onset could interfere with gonadotropin release as demonstrated in premenopausal women $^{44)}$.

For boys, one epidemiologic study found that maternal vegetarian diets containing large amounts of isoflavones are associated with hypospadias in male offspring ${ }^{45)}$. However, most studies failed to show a significant association between phytoestrogen exposure and pubertal onset $^{39,41)}$.

\section{Summary}

Several animal studies have demonstrated significant effects of phytoestrogen on sexual development, including altered pubertal timing, impaired estrous cyclicity and ovarian function, and altered function of the HPG axis. Human studies are also examining the possible effects of isoflavone exposure on sexual development in childhood. Especially during infancy, which is a critical period for growth and development, soy formula feeding may exert estrogenic effects on multiple organs including the mammary glands, gonads, and brain. In human studies, it is difficult to absolutely control other factors influencing clinical outcomes, such as diet, genetic factors, or other environmental disruptors. Further prospective human studies are needed that control these factors as much as possible to reveal the potential health effects of soy-based formulas or other sources of phytoestrogens on sexual development in children.

\section{Acknowledgment}

This work was supported by a grant 09182 KFDA600 from the Korea Food \& Drug Administration in 2010.

\section{References}

1. Setchell KD. Phytoestrogens: the biochemistry, physiology, and implications for human health of soy isoflavones. Am J Clin Nutr 1998;68(6 Suppl): 1333S-1346S.

2. Knight DC, Eden JA. A review of the clinical effects of phytoestrogens. Obstet Gynecol 1996;87(5 Pt 2):897-904.

3. Barnes S, Kirk M, Coward L. Isoflavones and their conjugates in soy foods: extraction conditions and analysis by HPLC-mass spectrometry. J Agric Food Chem 1994;42:2466-74.

4. Lee W, Lee SH, Ahn RS, Park MJ. Effect of genistein on the sexual maturation in immature female rats. Korean J Pediatr 2009;52:111-8.

5. Bateman HL, Patisaul HB. Disrupted female reproductive physiology following neonatal exposure to phytoestrogens or estrogen specific ligands is associated with decreased $\mathrm{GnRH}$ activation and kisspeptin fiber density in the hypothalamus. Neurotoxicology 2008;29:988-97.

6. Jefferson WN, Padilla-Banks E, Newbold RR. Adverse effects on female development and reproduction in CD-1 mice following neonatal exposure to the phytoestrogen genistein at environmentally relevant doses. Biol Reprod 2005;73:798-806.

7. Nagao T, Yoshimura S, Saito Y, Nakagomi M, Usumi K, Ono H. Reproductive effects in male and female rats of neonatal exposure to genistein. Reprod Toxicol 2001;15:399-411.

8. Kouki T, Kishitake M, Okamoto M, Oosuka I, Takebe M, Yamanouchi K. Effects of neonatal treatment with phytoestrogens, genistein and daidzein, on sex difference in female rat brain function: estrous cycle and lordosis. Horm Behav 2003;44:140-5.

9. Faber KA, Hughes CL Jr. Dose-response characteristics of neonatal expo- 
sure to genistein on pituitary responsiveness to gonadotropin releasing hormone and volume of the sexually dimorphic nucleus of the preoptic area (SDN-POA) in postpubertal castrated female rats. Reprod Toxicol 1993;7:35-9.

10. Couse JF, Lindzey J, Grandien K, Gustafsson JA, Korach KS. Tissue distribution and quantitative analysis of estrogen receptor-alpha (ERalpha) and estrogen receptor-beta (ERbeta) messenger ribonucleic acid in the wildtype and ERalpha-knockout mouse. Endocrinology 1997;138:4613-21.

11. Brandenberger AW, Tee MK, Lee JY, Chao V, Jaffe RB. Tissue distribution of estrogen receptors alpha (ER-alpha) and beta (ER-beta) mRNA in the midgestational human fetus. J Clin Endocrinol Metab 1997;82:3509-12.

12. Enmark E, Pelto-Huikko M, Grandien K, Lagercrantz S, Lagercrantz J, Fried G, et al. Human estrogen receptor beta-gene structure, chromosomal localization, and expression pattern. J Clin Endocrinol Metab 1997;82: 4258-65.

13. Sarkar FH, Li Y. Mechanisms of cancer chemoprevention by soy isoflavone genistein. Cancer Metastasis Rev 2002;21:265-80.

14. Kuiper GG, Lemmen JG, Carlsson B, Corton JC, Safe SH, van der Saag $\mathrm{PT}$, et al. Interaction of estrogenic chemicals and phytoestrogens with estrogen receptor beta. Endocrinology 1998;139:4252-63.

15. Ososki AL, Kennelly EJ. Phytoestrogens: a review of the present state of research. Phytother Res 2003;17:845-69.

16. Hwang CS, Kwak HS, Lim HJ, Lee SH, Kang YS, Choe TB, et al. Isoflavone metabolites and their in vitro dual functions: they can act as an estrogenic agonist or antagonist depending on the estrogen concentration. J Steroid Biochem Mol Biol 2006;101:246-53.

17. Martin PM, Horwitz KB, Ryan DS, McGuire WL. Phytoestrogen interaction with estrogen receptors in human breast cancer cells. Endocrinology 1978;103:1860-7.

18. Delclos KB, Bucci TJ, Lomax LG, Latendresse JR, Warbritton A, Weis $\mathrm{CC}$, et al. Effects of dietary genistein exposure during development on male and female CD (Sprague-Dawley) rats. Reprod Toxicol 2001;15:64763.

19. Padilla-Banks E, Jefferson WN, Newbold RR. Neonatal exposure to the phytoestrogen genistein alters mammary gland growth and developmental programming of hormone receptor levels. Endocrinology 2006; 147:4871-82.

20. Takagi H, Shibutani M, Lee KY, Lee HC, Nishihara M, Uneyama C, et al. Lack of modifying effects of genistein on disruption of the reproductive system by perinatal dietary exposure to ethinylestradiol in rats. Reprod Toxicol 2004;18:687-700.

21. Takashima-Sasaki K, Komiyama M, Adachi T, Sakurai K, Kato H, Iguchi $\mathrm{T}$, et al. Effect of exposure to high isoflavone-containing diets on prenatal and postnatal offspring mice. Biosci Biotechnol Biochem 2006;70:2874-82.

22. Casanova M, You L, Gaido KW, Archibeque-Engle S, Janszen DB, Heck HA. Developmental effects of dietary phytoestrogens in Sprague-Dawley rats and interactions of genistein and daidzein with rat estrogen receptors alpha and beta in vitro. Toxicol Sci 1999;51:236-44.

23. Lewis RW, Brooks N, Milburn GM, Soames A, Stone S, Hall M, et al. The effects of the phytoestrogen genistein on the postnatal development of the rat. Toxicol Sci 2003;71:74-83.

24. Pepling ME, Spradling AC. Mouse ovarian germ cell cysts undergo programmed breakdown to form primordial follicles. Dev Biol 2001;234:339-51.

25. Jefferson WN, Couse JF, Padilla-Banks E, Korach KS, Newbold RR. Neonatal exposure to genistein induces estrogen receptor (ER)alpha expression and multioocyte follicles in the maturing mouse ovary: evidence for ERbeta-mediated and nonestrogenic actions. Biol Reprod 2002;67: 1285-96.

26. Cimafranca MA, Davila J, Ekman GC, Andrews RN, Neese SL, Peretz J, et al. Acute and chronic effects of oral genistein administration in neonatal mice. Biol Reprod 2010;83:114-21.

27. Iguchi T, Fukazawa Y, Uesugi Y, Takasugi N. Polyovular follicles in mouse ovaries exposed neonatally to diethylstilbestrol in vivo and in vitro. Biol Reprod 1990;43:478-84.

28. Jefferson WN, Padilla-Banks E, Newbold RR. Disruption of the female reproductive system by the phytoestrogen genistein. Reprod Toxicol 2007; 23:308-16.

29. Freeman ME. Neuroendocrine control of the ovarian cycle of the rat. In: Knobil E, Neil JD, editors. The physiology of reproduction. New York: Raven Press, 1994:613-58.

30. Losa SM, Todd KL, Sullivan AW, Cao J, Mickens JA, Patisaul HB. Neonatal exposure to genistein adversely impacts the ontogeny of hypothalamic kisspeptin signaling pathways and ovarian development in the peripubertal female rat. Reprod Toxicol 2011;31:280-9.

31. Morton MS, Chan PS, Cheng C, Blacklock N, Matos-Ferreira A, Abranches-Monteiro L, et al. Lignans and isoflavonoids in plasma and prostatic fluid in men: samples from Portugal, Hong Kong, and the United Kingdom. Prostate 1997;32:122-8.

32. Morton MS, Arisaka O, Miyake N, Morgan LD, Evans BA. Phytoestrogen concentrations in serum from Japanese men and women over forty years of age. J Nutr 2002;132:3168-71.

33. Uehar M, Arai Y, Watanabe S, Adlercreutz H. Comparison of plasma and urinary phytoestrogens in Japanese and Finnish women by time-resolved fluoroimmunoassay. Biofactors 2000;12:217-25.

34. Foster WG, Chan S, Platt L, Hughes CL Jr. Detection of phytoestrogens in samples of second trimester human amniotic fluid. Toxicol Lett 2002; 129:199-205.

35. Setchell KD, Zimmer-Nechemias L, Cai J, Heubi JE. Exposure of infants to phyto-oestrogens from soy-based infant formula. Lancet 1997;350:237.

36. Freni-Titulaer LW, Cordero JF, Haddock L, Lebron G, Martinez R, Mills JL. Premature thelarche in Puerto Rico. A search for environmental factors. Am J Dis Child 1986;140:1263-7.

37. Zung A, Glaser T, Kerem Z, Zadik Z. Breast development in the first 2 years of life: an association with soy-based infant formulas. J Pediatr Gastroenterol Nutr 2008;46:191-5.

38. Bernbaum JC, Umbach DM, Ragan NB, Ballard JL, Archer JI, SchmidtDavis $\mathrm{H}$, et al. Pilot studies of estrogen-related physical findings in infants. Environ Health Perspect 2008;116:416-20.

39. Strom BL, Schinnar R, Ziegler EE, Barnhart KT, Sammel MD, Macones GA, et al. Exposure to soy-based formula in infancy and endocrinological and reproductive outcomes in young adulthood. JAMA 2001;286:807-14.

40. Wolff MS, Britton JA, Boguski L, Hochman S, Maloney N, Serra N, et al. Environmental exposures and puberty in inner-city girls. Environ Res 2008;107:393-400.

41. Cheng G, Remer T, Prinz-Langenohl R, Blaszkewicz M, Degen GH, Buyken AE. Relation of isoflavones and fiber intake in childhood to the timing of puberty. Am J Clin Nutr 2010;92:556-64.

42. Adgent MA, Daniels JL, Rogan WJ, Adair L, Edwards LJ, Westreich D, et al. Early-life soy exposure and age at menarche. Paediatr Perinat Epidemiol 2012;26:163-75. 
43. Kim J, Kim S, Huh K, Kim Y, Joung H, Park M. High serum isoflavone concentrations are associated with the risk of precocious puberty in Korean girls. Clin Endocrinol (Oxf) 2011;75:831-5.

44. Cassidy A, Bingham S, Setchell KD. Biological effects of a diet of soy protein rich in isoflavones on the menstrual cycle of premenopausal women.
Am J Clin Nutr 1994;60:333-40.

45. North K, Golding J. A maternal vegetarian diet in pregnancy is associated with hypospadias. The ALSPAC Study Team. Avon Longitudinal Study of Pregnancy and Childhood. BJU Int 2000;85:107-13. 